\title{
Experimental Studies on Cardiac Resuscitation
}

\section{Studies on Resuscitation of Cardiac Arrest Caused by Various Conditions}

By

\section{Togo Horiuchi}

(垉內 藤 吾)

From the Surgical Clinic of Prof. S. T. Katsura, Faculty of Medicine, Tohoku University, Sendai

(Received for publication December 10, 1954)

Among the various causes of acute cardiac arrest encountered daily, such as electrocution, vago-vagal reflex, mechanical stimuli of the heart and percardium, asphyxia, coronary occlusion, cardiac dysfunction due to oversupply of acetylcholine or epinephrine, hemorrhage, improper administration of anesthetics, etc., the first three causes can be obviously prevented by countershocks and massage as demonstrated from the experimental results described in my first report. Cardiac arrest, however, caused by the latter five accidents are due to complicated conditions. It is natural that the method of resuscitation should be different from the first three causes. As our knowledge is poor concerning the latter conditions, the method of resuscitation was studied experimentally as described in this account.

\section{EXPERIMENTAL}

\section{Cardiac Arrest Caused by Obstruction of Respiratory Tract}

Method: 11 adult dogs were used. Cardiac arrest was caused by obstructing the intubated endotracheal tube. Resuscitation was attempted by release of obstruction.

Result: After obstructing the respiratory tract, the lung became atelectatic within 3 minutes and the pulse showed transient gallop rhythm with temporary rise of blood pressure and changed to bradycardia. 'The cardiac rhythm became weak and a standstill was noticed 8-13 minutes later. When the obstruction of the respiratory tract was relieved and energetic artificial respiration with $100 \%$ oxygen was attempted with cardiac massage, the cardiac tonus was good and the pulsation gradually improved. Frequent appearance of extrasystoles and atrioventricular dissociation, however, appeared and changed into ventricular fibrillation in many cases. Many cases of ventricular fibrillation were incited 
TABLE I

Cardiac Arrest Caused by Long Obstruction of Respiratory Tract

\begin{tabular}{|c|c|c|c|c|c|}
\hline $\begin{array}{l}\text { Duration of } \\
\text { obstruction } \\
\text { of airway } \\
\text { (min.) }\end{array}$ & $\begin{array}{l}\text { State of } \\
\text { cardiac } \\
\text { arrest }\end{array}$ & $\begin{array}{l}\text { Time till restora- } \\
\text { tion of heart } \\
\text { beat after release } \\
\text { of airway }\end{array}$ & $\begin{array}{l}\text { Complication } \\
\text { during } \\
\text { cardiac } \\
\text { resuscitation }\end{array}$ & Remark & $\begin{array}{l}\text { Method of } \\
\text { resuscitation }\end{array}$ \\
\hline 8 & Standstill & 6 & V.F. & revived & 1) Release of obst. \& \\
\hline 9 & $"$ & 3 & $\begin{array}{l}\text { Rupture of } \\
\text { R. Vent. }\end{array}$ & $"$ & $\begin{array}{l}\text { pure } \mathrm{O}_{2} \text { insuftl. } \\
\text { 2) C.M. }\end{array}$ \\
\hline 10 & $"$ & 19 & none & $"$ & 3) E.S. \\
\hline 10 & " & 6 & none & $"$ & 4) Injection of epine- \\
\hline 11 & $"$ & 6 & V.F. & $"$ & phrine (8 cases) \\
\hline 13 & $"$ & 10 & $"$ & $"$ & $\begin{array}{l}\text { 5) Injection of pro- } \\
\text { caine amid( } 7 \text { cases })\end{array}$ \\
\hline 13 & $"$ & 12 & $"$ & $"$ & \\
\hline 14 & $"$ & 8 & ", & $"$ & \\
\hline 14 & V.F. & 7 & $\begin{array}{l}\text { Rupture of } \\
\text { R. Vent. }\end{array}$ & died & \\
\hline 15 & Standstill & 10 & V.F. & revived & \\
\hline 15 & " & 30 & $"$ & died & \\
\hline
\end{tabular}

after cardiac injection of epinephrine. In this case, ventricular fibrillation could be hardly removed by single use of countershocks. Injection of 50-100 mg. of procain amide into the heart followed by countershocks was frequently found to be efficient.

During powerful cardiac massage, the right ventricle was ruptured by manual pressure of the right thumb in two cases. All cases survived which had obstruction of the respiratory tract removed within 13 minutes.

\section{Cardiac Arrest Caused by Ligation of Coronary Arteries}

Method: As shown in Table II, the coronary arteries were dissected and only ligated at different points of the coronary arteries in 32 cases. In the cases of $\mathrm{A}, \mathrm{B} \& \mathrm{C}$, ventricular fibrillation was recognized within 2-8 minutes; In $\mathrm{D} \& \mathrm{E}$, spontaneous occurrence of ventricular fibrillation was not observed for 20 minutes. Ventricular fibrillation was caused electrically and removed later.

Result: In the groups A, B \& C, ventricular fibrillation could not be removed by mere countershocks. They were resuscitated by cardiac massage followed by countershocks after the release of the ligature: Fig. I shows the electrocardiographic findings in the group C. Generally speaking, ventricular fibrillation caused by the ligature at $\mathrm{D} \& \mathrm{E}$ was removed by countershocks. 1/3 of ventricular fibrillation at $D$, however, 
TABLE II

Cardiac Arrest Caused by Ligation of Coronary Artery

(spont.), sponteneous occurrence of V.F.; (elect.), V. F. caused by E. S.

\begin{tabular}{|c|c|c|c|c|c|}
\hline Group & $\begin{array}{l}\text { Ligated portion of } \\
\text { coronary artery }\end{array}$ & Cases & $\begin{array}{l}\text { Time from liga- } \\
\text { tion to occur- } \\
\text { rence of } \\
\text { V.F. (min.) }\end{array}$ & Remark & $\begin{array}{l}\text { Method of } \\
\text { resuscitation }\end{array}$ \\
\hline A. & $\begin{array}{l}\text { Origin of left } \\
\text { coronary artery }\end{array}$ & 1 & 2 (spont.) & died & \\
\hline B. & $\begin{array}{l}\text { Origin of } \\
\text { circumflex branch }\end{array}$ & 5 & 2-5 (spont.) & revived & $\begin{array}{l}\text { 1) Release of ligat. 2) } \\
\text { E.S. 3) Inhalation o } \\
\mathrm{O}_{2}\end{array}$ \\
\hline C. & $\begin{array}{l}\text { Origin of ant. } \\
\text { descend. branch }\end{array}$ & 9 & $\begin{array}{l}2.1 / 4-8 \\
\text { (spont.) }\end{array}$ & & \\
\hline D. & $\begin{array}{l}\text { Midportion of ant. } \\
\text { descend. branch }\end{array}$ & 13 & (elect.) & & $\begin{array}{l}\text { 1) E.S. } \\
\text { 2) Inhalation of } \mathrm{O}_{2}\end{array}$ \\
\hline E. & $\begin{array}{l}\text { Origin of right } \\
\text { coronary artery }\end{array}$ & 4 & (elect.) & & \\
\hline
\end{tabular}

A $\quad B \quad C$

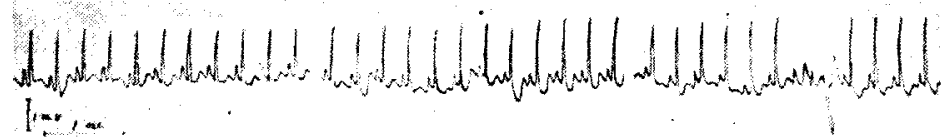

D

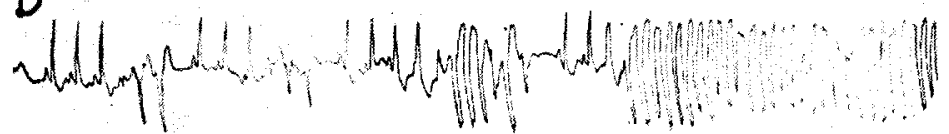

E $\quad F \quad$ G $\quad H$

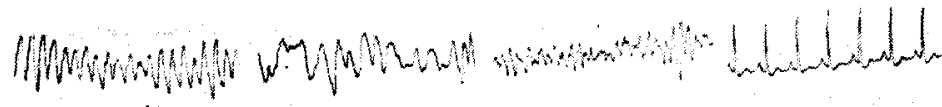

Fig. 1. ECG : Ventricular fibrillation caused by ligation of origin of ant. descend. branch of left coronary artery, lead II : A. preoperative control tracing; B. tracing $2 \mathrm{~min}$. after ligation, ST segment depression; C, $31 / 2 \mathrm{~min}$. initiation of premature beat; D, $5 \mathrm{~min}$., transfer to ventricular fibrillation; E, tracing $1 \mathrm{~min}$, after fibrillation; F. $21 / 2 \mathrm{~min}$; G, cardiac massage $3 \mathrm{~min}$, after fibrillation; H, $2 \mathrm{~min}$. after removal of $\mathrm{V}$. F. by release of ligature with countershocks.

showed frequent occurrence of extrasystoles after removal of ventricular fibrillation. In many cases the heart became rumbling and started to fibrillate. In order to resuscitate the heart, the ligature had to be released. One of the cases ligated at $\mathrm{E}$, countershock alone did not remove the fibrillation. Injection of $100 \mathrm{mg}$. of procaine amide followed by countershocks proved to be satisfactory. At first, EGG showed rise of 
the ST segment and showed monophasic curve with gradual return to normal curve by massage.

\section{Cardiac Arrest Caused by Acetyl Choline Injection}

Method : 4 dogs were used. Cardiac arrest was caused by intravenous injection of acetyl choline (7-14 mg./kg.) and cardiac resuscitation was attempted.

Result: As shown in Table III, cardiac standstill occurred 5-8

TABLE III

Cardiac Arrest Caused by Injection of Acetyl Choline

\begin{tabular}{|c|c|c|c|c|c|c|}
\hline Case No. & $\begin{array}{c}\text { Body } \\
\text { weight } \\
\text { (kg.) }\end{array}$ & $\begin{array}{c}\text { Dosis } \\
\text { (intravenous } \\
\text { injection) }\end{array}$ & $\begin{array}{l}\text { Time from } \\
\text { inj. till } \\
\text { cardiac } \\
\text { standstill }\end{array}$ & $\begin{array}{l}\text { Time till } \\
\text { restor. of } \\
\text { heart beat }\end{array}$ & Remark & $\begin{array}{l}\text { Method of } \\
\text { resuscitation }\end{array}$ \\
\hline 108 & 10 & $8 \mathrm{mg} . / \mathrm{kg}$. & $5 \mathrm{sec}$. & $3 \mathrm{~min}$. & revived & $\begin{array}{l}\text { 1) C.M. } \\
\text { 2) Inhalation of } \mathrm{O}_{2}\end{array}$ \\
\hline 109 & 6.5 & $7 \mathrm{mg} \cdot / \mathrm{kg}$. & $8 \mathrm{sec}$. & $9 \mathrm{~min}$. & $"$ & \\
\hline 110 & 12 & $7 \mathrm{mg} \cdot / \mathrm{kg}$. & 6 sec. & $3 \mathrm{~min}$. & $"$ & 1) Injection of \\
\hline 111 & 9 & $14 \mathrm{mg} \cdot / \mathrm{kg}$. & $5 \mathrm{sec}$. & $8 \mathrm{~min}$. & $"$ & 2) Inhalation of $\mathrm{O}_{2}$ \\
\hline
\end{tabular}

A

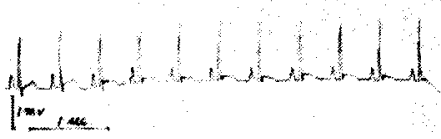

C

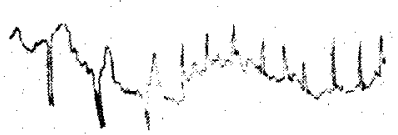

B

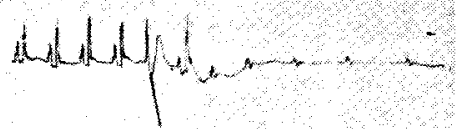

D

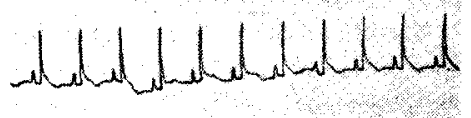

Fig. 2. ECG : Cardiac arrest caused by acetyl choline injection, lead II : A. preoperative control tracing; $\mathrm{B}$, tracing 5 sec. after injecting 80 mg. acetyl choline, transfer to cardiac standstill ; C, 1 min. after starting of cardiac massage; D, $3 \mathrm{~min}$, after starting massage, sinus rhythm.

seconds after intravenous injection of acetyl choline. The tone of cardiac muscle was good. Several strong cardiac contractions appeared by cardiac massage at first and were followed with normal cardiac contractility 3-9 minutes later. Fig. 2 shows the ECG of case 10. This kind of cardiac standstill responded to intracardiac injection of $5 \mathrm{mg}$. of 
atropine and rapidly returned to normal sinus rhythm.

\section{Cardiac. Arrest Caused by Acute Massive Hemorrhage}

Method: 5 dogs were used. A glass canule was inserted into the femoral artery and blood was withdrawn to the extent of $23 \mathrm{cc} .-58 \mathrm{cc}$. pro kilogram of body weight till cardiac arrest occurred. Following this procedure, intraarterial transfusion was immediately performed with strong cardiac massage and cardiac stimulants such as epinephrine and vitacamphor were injected to resuscitate the heart.

Result: As shown in Table IV, in the case of massive blood loss, most cases went into cardiac standstill within 30 minutes. All cases showed flaccid cardiac muscle and died in spite of massage and injection of epinephrine etc.

Fig. 3 shows the ECG and EEG findings in case $116 ; 2^{\prime} 30^{\prime \prime}$ after blood was withdrawn: amount of blood loss $28 \mathrm{cc} . / \mathrm{kg}$. blood pressure $60 \mathrm{~mm}$. $\mathrm{Hg}$. ECG : lowering of ST segment \& tachycardia. EEG : slow waves. Forced respiration started. $6^{\prime}$ : amount of blood loss $45 \mathrm{cc} . / \mathrm{kg}$. blood pressure, $20 \mathrm{~mm}$. $\mathrm{Hg}$., slight amount of bleeding, strong heart murmur audible. EEG : cerebral potential almost disappeared. 14': amount of blood loss $58 \mathrm{cc} . / \mathrm{kg}$., heart

\section{TABLE IV}

Cardiac Arrest Caused by Rapid Blood Loss

\begin{tabular}{|c|c|c|c|c|c|}
\hline Cases No. & $\begin{array}{l}\text { Body } \\
\text { weight } \\
\text { (kg.) }\end{array}$ & $\begin{array}{l}\text { Volume } \\
\text { bled }\end{array}$ & $\begin{array}{l}\text { Time from begining } \\
\text { to cardiac standstill } \\
\text { (min.) }\end{array}$ & Remark & $\begin{array}{l}\text { Method of } \\
\text { resuscitation }\end{array}$ \\
\hline 112 & 14 & $28 \mathrm{cc} . / \mathrm{kg}$. & 34 & died & 1) Intra-arterial \\
\hline 113 & 10 & $23 \mathrm{cc} . / \mathrm{kg}$. & 28 & $"$ & transfusion \\
\hline 114 & 6 & $62 \mathrm{cc} . / \mathrm{kg}$. & 36 & ”, & 2) C.M. \\
\hline 115 & 8 & $31 \mathrm{cc} . / \mathrm{kg}$. & 31 & " & 3) Injection of epineph- \\
\hline 116 & 10 & $58 \mathrm{cc} . / \mathrm{kg}$ & 30 & " & \\
\hline
\end{tabular}

murmur not audible, pulsation hardly felt. ECG: sinus rhythm (Fig. 3, B). $16^{\prime}$ : spontaneous respiration stopped, pupil completely dilated. $20^{\prime}$ : cardiac fibrillation. $21^{\prime}$ : intraarterial transfusion with cardiac massage. 29' : transfusion $60 \mathrm{cc} . / \mathrm{kg}$., blood pressure during cardiac massage $0-20 \mathrm{~mm}$. $\mathrm{Hg}$ : tonus of the heart muscle slightly improved by injection of epinephrine and calcium chloride. $46^{\prime}$ : ventricular fibrillation removed by countershocks (Fig. 3, D.). $60^{\prime}$ : cardiac tonus not recovered and death.

\section{Cardiac Arrest Caused by Rapid Intravenous Injection of Barbiturates}

Method: 7 dogs were used. Cardiac arrest was caused by rapid 


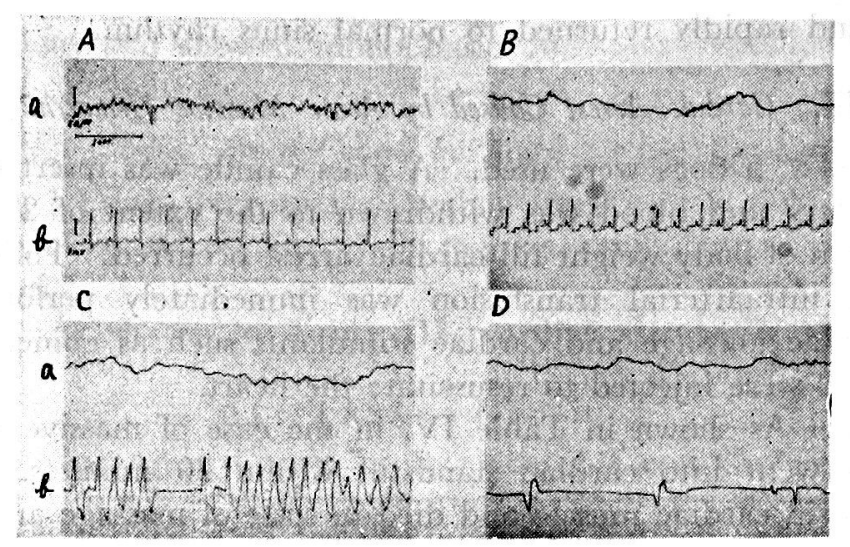

Fig. 3. EEG (a) ECG (b): Cardiac arrest caused by hemorrhage : A. preoperative control tracing; B, 14 min. after hemorrhage, EEG flat ; C, $20 \mathrm{~min}$, after hemorrhage, ECG transfer to vent. fibrillation; D, 46 min., fibrillation removed by E. S., ECG automatic by lower center.

intravenous injection of $30-50 \mathrm{mg}$. barbital sodium. Subsequently, cardiac resuscitation was attempted.

Result: As shown in Table V, cardiac standstill occurred within 5 seconds- 6 minutes after intravenous injection. Immediately afterwards, cardiac massage was performed. Cardiac muscle, however, was flabby and soft. Blood did not circulate through the coronary vessels and cardiac rhythm could not be restored. The effect of epinephrine was only temporary and all cases proved fatal eventually. Case 121 showed strong cardiac contraction by cardiac massage. Respiration and brain stem reflex, however, did not appear and it died 120 minutes later.

TABLE V

Cardiac Arrest Caused by Rapid Injection of Barbital-Sodium

\begin{tabular}{|c|c|c|c|c|c|c|}
\hline $\begin{array}{l}\text { Case } \\
\text { No. }\end{array}$ & $\begin{array}{c}\text { Body } \\
\text { weight } \\
\text { (kg.) }\end{array}$ & Drug & $\begin{array}{c}\text { Dosis } \\
\text { (intravenous } \\
\text { injection) }\end{array}$ & $\begin{array}{l}\text { Time from } \\
\text { inj. to } \\
\text { card. stand. }\end{array}$ & Remark & $\begin{array}{l}\text { Method of } \\
\text { resuscitation }\end{array}$ \\
\hline 117 & 7 & $\begin{array}{l}\text { pent. } \\
\text { barbit }\end{array}$ & $43 \mathrm{mg} \cdot / \mathrm{kg} \cdot / 30 \mathrm{sec}$ & $6 \mathrm{~min}$. & died & $\begin{array}{l}\text { 1) C.M. } \\
\text { 2) Injection of }\end{array}$ \\
\hline 118 & 15 & $"$ & $34 \mathrm{mg} . / \mathrm{kg} . / 1 \mathrm{~min}$. & $5 \mathrm{sec}$. & $"$ & $\begin{array}{l}\text { epinephrine, } \\
\mathrm{CaCl}_{2} \&\end{array}$ \\
\hline 119 & 12 & $"$ & $40 \mathrm{mg} . / \mathrm{kg} . / 30 \mathrm{sec}$. & $5 \mathrm{~min}$. & $"$ & $\mathrm{BaCl}_{2}^{2}$ \\
\hline 120 & 9 & $"$ & $50 \mathrm{mg} . / \mathrm{kg} . / 30 \mathrm{sec}$. & $3 \mathrm{~min}$. & $"$ & \\
\hline 121 & 8 & $\begin{array}{l}\text { methyl-hexa- } \\
\text { barbit. }\end{array}$ & $50 \mathrm{mg} . / \mathrm{kg} \cdot / 20 \mathrm{sec}$. & $4 \mathrm{~min}$. & $"$ & \\
\hline 122 & 10 & & $40 \mathrm{mg} . / \mathrm{kg} . / 15 \mathrm{sec}$. & $2 \mathrm{~min}$. & $"$ & \\
\hline 123 & 11 & & $30 \mathrm{mg} . / \mathrm{kg} . / 10 \mathrm{sec}$. & $2 \mathrm{~min}$. & " & \\
\hline
\end{tabular}




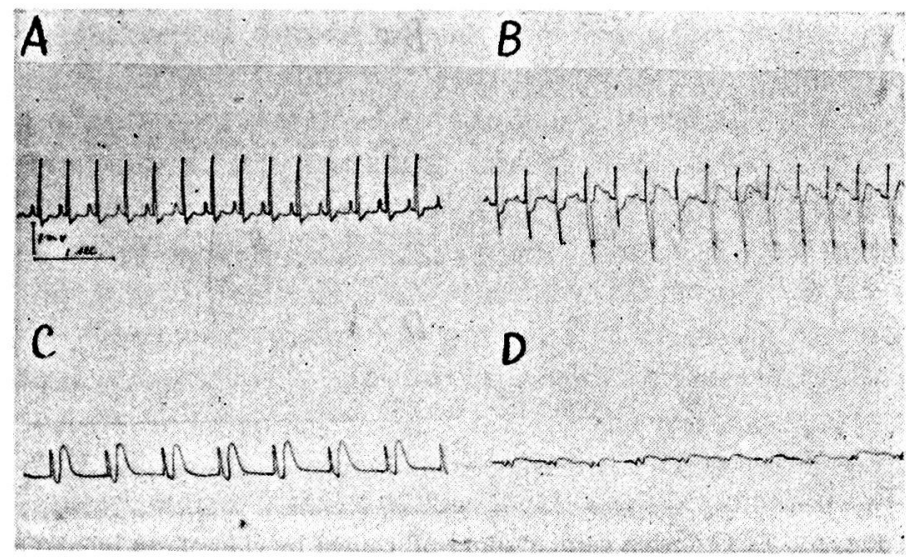

Fig. 4. ECG during cardiac standstill caused by intravenous injection of pentothal-sodium: A. preoperative control tracing; B, 10 sec. after injection $43 \mathrm{mg} . / \mathrm{kg}$. in $30 \mathrm{sec}$., deep S ; C, $6 \mathrm{~min}$., disappearance of $\mathrm{P}$ wave, low voltage of $R$, large $T$; $D, 30 \mathrm{~min}$. after massage ; massage. injection of epinephrine, $\mathrm{CaCl}_{2} \& \mathrm{BaCl}_{2}$ ineffective.

Fig. 4 shows the ECG findings in case 117.

\section{Cardiac Arrest Caused by Chloroform Inhalation}

Method: 5 dogs were used. Chloroform was either injected into the trachea in doses of $0.2-0.3 \mathrm{cc}$. pro kilogram of body weight, or in sufflation of large amount chloroform was rapidly applied with an anesthetic appratus, to cause cardiac arrest, and cardiac resuscitation was attempted.

Result: As shown in Table VI all cases showed cardiac standstill 20-30 seconds after the begining of inhalation of chloroform. After the start of cardiac massage, all cases showed ventricular fibrillation. After the start of cardiac massage, all cases showed ventricular fibrillation. They were temporarily removed by injection of procaine amide followed

TAB LE VI

Cardiac Arrest Caused by Chloroform Inhalation

\begin{tabular}{|c|c|c|c|c|c|c|}
\hline $\begin{array}{l}\text { Case } \\
\text { No. }\end{array}$ & $\begin{array}{c}\text { Body } \\
\text { weight } \\
\text { (Kg.) }\end{array}$ & Method & Dosis & $\begin{array}{l}\text { Time till } \\
\text { card. stand. }\end{array}$ & Remark & $\begin{array}{l}\text { Method of } \\
\text { resuscitation }\end{array}$ \\
\hline 124 & 9 & $\begin{array}{l}\text { Intratracheal } \\
\text { inhalation }\end{array}$ & 0.2 cc. $/ \mathrm{kg}$. & $25 \mathrm{sec}$. & died & $\begin{array}{l}\text { 1) C.M. } \\
\text { 2) E.S. }\end{array}$ \\
\hline 125 & 6 & " & $0.3 \mathrm{cc} . / \mathrm{kg}$. & $32 \mathrm{sec}$. & $"$ & $\begin{array}{l}\text { 3) injection of } \\
\text { epinephrine, }\end{array}$ \\
\hline 126 & 12 & anesthetic cap & ? & 60 sec. & $"$ & $\mathrm{CaCl}_{2} \&$ pro- \\
\hline 127 & 15 & intratracheal & 0.2 cc. $/ \mathrm{kg}$. & $30 \mathrm{sec}$. & $"$ & \\
\hline 128 & 8 & " & $0.3 \mathrm{cc} . / \mathrm{kg}$. & $20 \mathrm{sec}$. & $"$ & \\
\hline
\end{tabular}




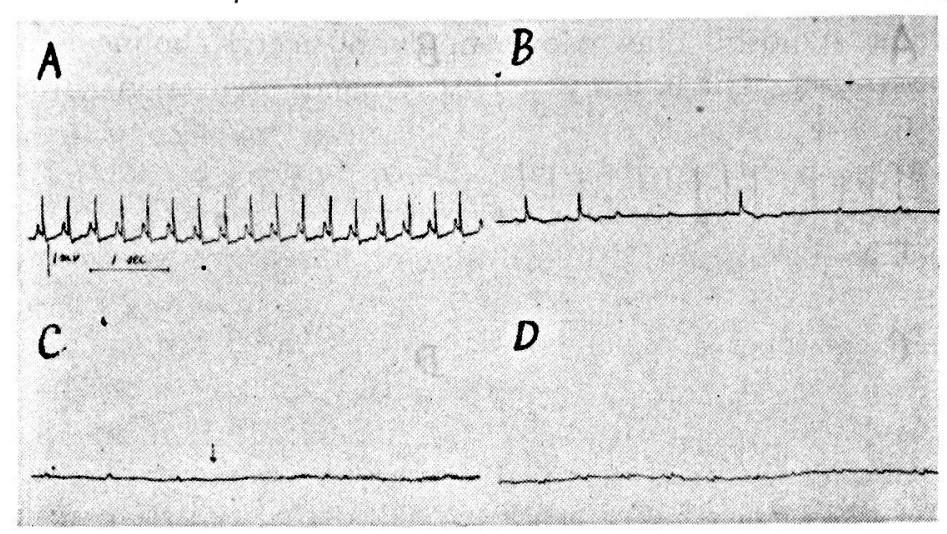

Fig. 5. ECG during cardiac standstill caused by chloroform inhalation. A, preoperative control tracing; B, $30 \mathrm{sec}$. after inhalation, abrupt disappearance of QRS complexs, prolongation of P-P interval ; C, $40 \mathrm{sec}$., transfer to auricular flutter (arrow) ; D, 10 min., in spite of removal of V.F. by E.S., massage, injection of epinephrine etc. were ineffective, no vigorous heart beat restored.

by countershocks. Ventricular fibrillation, however, supervened again. Cardiac muscles were completely flabby and soft. Blood pressure did not rise by cardiac massage. Injection of epinephrne was not only ineffective, but excited ventricular fibrillation. All cases died eventually. Fig. 5 shows the ECG of Case 125.

\section{Discussion}

Cardiac arrest due to tracheal obstruction frequently occurs clinically such cases as intratracheal aspiration of vomitus, blood, tracheal obstruction due to sputum, laryngeal spasm, etc. Their prognosis, however, are relatively good. When the obstructon of the trachea is removed and assisted respiration by $100 \%$ oxygen and energetic cardiac massage are performed, cases with the tracheal obstruction released with in 13 minutes recover rapidly. When bradycardia develops during tracheal obstruction, section of the left vagus nerve causes tachycardia. ${ }^{1)}$ This phenomenon is due to increase of vagus irritability.

It is evident by my experiment and Wigger's experiment ${ }^{2}$ ) that ventricular fibrillation following coronary insufficiency can only be cured by release of the causative factor, i.e., removal of occulusion and recovery of cardiac ischemia. Ventricular fibrillation due to occlusion of peripheral branches of the coronary artery and the right coronary artery, however, can be removed by countershocks alone. Administration of procaine amide with performance of cardiac massage at the same time, however, is much better. 
Cardiac standstill due to oversupply of acetyl choline is attributed to increase of vagus irritability. This responds well to injection of atropine, and cardiac massage. The prognosis is usually good. All cases of cardiac standstill by bleeding turned out to be fatal. Negovski, Winkelbauer et al. ${ }^{3,4)}$ stated that if cardiac resuscitation can be started within 5-6 minutes from " clinical death," the heart will recover. The standard of clinical death is, however, very obscure from my study. It seems to be reasonable to set the standard of death at the disappearing time of brain potentials. This is, however, difficult for clinical application. As the heart continues to beat till the last moment, the changes of ECG findings are not remarkable, and the heart is hard to recover once it stops beating. Measures against bleeding to death are to watch the fall of blood pressure, change of pulse and amount of blood loss, and to control the blood transfusion.

Cardiac arrest due to narcotics, i.e., barbiturates, and chloroform have bad prognosis. The muscles of an arrested heart are flabby, and neither massage nor injections of epinephrine, calcium chloride, cedilanid, and barium chloride are effective. Despite temporary return of pulsation, death comes on with disappearance of respiration and reflexes. As this kind of cardiac arrest is due to intoxication of heart muscle, brain and other vital organs, the prognosis is influenced by the amount of administration and speed of injection of the drugs. Therefore, the measure against this catastrophe is to select narcotics carefully and to prevent the accident beforehand by avoiding over-administration of the drugs. If possible, measures for detoxication is important.

Resuscitation of the arrested heart due to chloroform has been carried out many times since the first experiment by Schiff (1874). Chloroform, however, is abandoned as a narcotic at present time and became one of the classical drugs. One of its causes may be due to its difficulty to resuscitate the arrested heart as described above.

Beck et al..$^{5}$ stated that ventricular fibrillation were apt to be caused by localized ischemia or anoxia of the heart, while cardiac standstill was brought about by generalized ishemia or anoxis. My experiment gave the same results. Except ventricular fibrillation caused by coronary occlusion, the cases showed cardiac standstill with few exceptions. Ventricular fibrillation occurred when epinephrine was injected within a heart under cardiac standstill due to obstruction of the trachea and inhalation of chloroform. On the contrary, in spite of intravenous injection of large dosage of epinephrine into a normal beating heart, the heart became rumbling but it was never thrown into fibrillation. From this finding, epinephrine acts as a secondary stress upon a very sensitive heart and excites ventricular fibrillation. The mechanical stimuli ${ }_{\mathrm{f}}$ 
cardiac massage also acts as a secondary stress and induces ventricular fibrillation. When cardiac massage is required, it should be done gently during the refractory phase of cardiac muscle, i.e., the systolic phase to avoid unnecessary stimulation of the heart muscles. I should like to call this manner "assisted massage." In such cases, as ventricular fibrillation is hard to remove by countershocks, it is desirable to use countershocks after cardiac sensibility is reduced by administration of procaine amide as shown by the experiment of Mautz et al. ${ }^{6}$

\section{Summary}

Cardiac arrest frequently encountered in routine treatments was caused experimentally and resuscitation was attempted.

1. Occulusion of trachea causes cardiac standstill. When obstruction is released within 13 minutes and artificial respiration with $100 \%$ oxygen is carried out, cardiac rhythm recovers by cardiac massage.

2. Occlusion of the main stem of left coronary artery causes ventricular fibrillation. It cannot be abolished by countershocks without release of obstruction. Ventricular fibrillation by occlusion of right coronary artery, and peripheral branch of left coronary artery can be both successfully removed by electric shocks.

3. Oversupply of acetyl choline causes cardiac standstill. This can be resuscitated satisfactorily by cardiac massage and injection of atropine.

4. Acute massive bleeding causes cardiac standstill. Once the cardiac rhythm stops, resuscitation is almost impossible. In such cases, ECG, or macroscopic observation of the heart rhythm do not serve as a danger signal of cardiac arrest. Adequate control of transfusion should be carried out with attention to the amount of lost blood, changes of blood pressure and pulsation.

5. Narcotics as barbiturates and chloroform cause cardiac arrest. As their prognoses are bad, prevention of their occurrences should be carried out before hand.

6. The effect of injection of epinephrine, procaine amide and cardiac massage upon the heart muscle were discussed. Especially, assisted massage should be carried out carefully, when the irritablity of heart muscle is increased.

\section{References}

1) Greene \& Gilbert, Am. J. Physiol., 1922, 60, 155.

2) Wiggers, Am. J. Physiol., 1936, 116, 161.

3) Negovski, Am. Rev. Sov. Med., 1945, 2, 303, 408, 491.

4) Winkelbauer, Deut. Ztschr. Chir., 1935, 245, 1. 
5) Beck \& Mautz, Ann. Surg., 1937, 106, 525.

6) Mautz, J. Thorac. Sug., 1936, 5, 612. 